ELORE (ISSN 1456-3010), vol. $13-1 / 2006$.

Julkaisija: Suomen Kansantietouden Tutkijain Seura ry. Taitto: Jukka Talve.

[http://cc.joensuu.fi/ /oristi/1_06/ark1_06.pdf]

FOLKLIFE IN FOCUS

INTERVIEW WITH PROFESSOR LAURA STARK

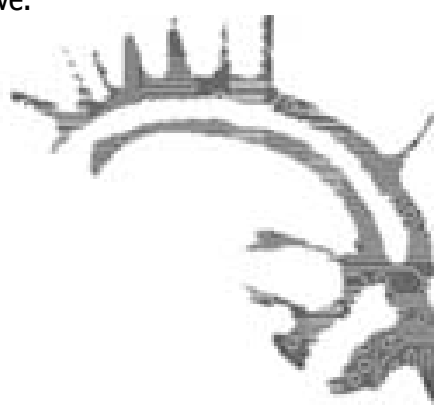

Laura Aro \& Maarit Knuuttila

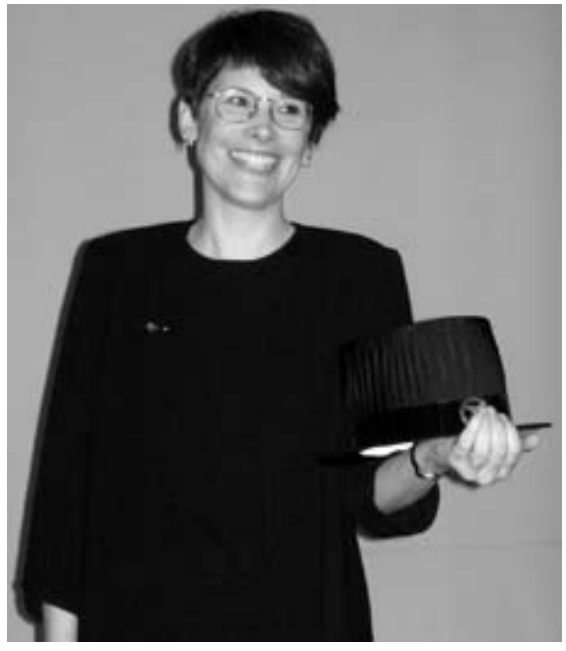

Laura Stark in her inangural ceremony at the University of Jyväskylä,

November 23, 2005.

\title{
BACKGROUND
}

Tell us about your background, your family history, student days, major subject, secondary subject, special interests at the university?

I grew up in a small farming town in northern California in a lower-middle-class family. I was not very interested in higher education until I came to Finland, completely by chance, as a high school exchange student. I lived in Nastola for a year, sponsored by the Rotary Club. It was a wonderful experience. I had an opportunity to travel around Europe a bit, and came to the conclusion that I wanted to study languages. My plan was to come back and live in Europe, preferably in Finland. 
When I returned from my exchange year, I attended the University of California at Davis, which was only an hour away from my home town. There I studied German, Russian, and even a bit of Swedish. I soon realized that what really interested me was not just the languages themselves, but how languages work. So I decided to major in General Linguistics and minor in German, and after roughly three and a half years, I received my Bachelor's degree in that field.

In the United States, many students stop their academic studies after the Bachelor's degree and go into business or working for the government. I knew that I did not want to continue as a student in linguistics which I considered too abstract. Luckily enough, in my last semester before I graduated with my Bachelor's degree, I met a professor of anthropology who was researching an ancient writing system from Mexico which had not yet been deciphered. This writing system was older than Mayan writing, and a whole tablet full of symbols had just been discovered in 1986. I began to work with Professor Macri on compiling a catalogue of these symbols in order to determine what kind of writing system it might represent.

Our work took more than two years and because of it, I decided to apply to the UC Davis Department of Anthropology as a postgraduate student. More specifically, I was interested in their Linguistic Anthropology programme, which in many ways covered the same topics and concerns as folklore studies in Finland. I was accepted, and after one year took my Master's Degree examination. At the University of California, Master's Degree students do not write a thesis, they take an examination which lasts several days, and their answers are reviewed by a panel of five professors. For my examination, I decided to concentrate on folklore, orality and literacy, and the Finno-Ugric language areas. After passing my Master's examination, I was free to begin working on my doctoral thesis.

I knew that I wanted to write my thesis about Finnish folklore, but what topic to choose? During this period, two things happened. First, I discovered Suomen Kansan Vanbat Runot, the 34-volume series containing nearly all of the Kalevala-meter poems ever recorded from Finland and Karelia. The incantations (loitsut) used by women interested me in particular, and so I decided to write my doctoral dissertation about traditional Finnish women's magic. Second, I received a Fulbright scholarship to study at the University of Helsinki for a year. This allowed me to come to the Finnish Literature Society Folklore Archives and study the archival source materials in person. The Fulbright was originally intended for one year only (1992-93), but I stayed in Finland after the first year, and I've been here ever since! 
FOLKLOFE IN FOCUS: INTERVIEW OF PROFESSOR LAURA STARK

\section{FINNISH FOLKLORE}

How and when did you get interested in folklore? Did you get familiar with the so-called Finnish method, or finnish shcolars?

I had read something about Finnish folklore studies before I came to Finland, but I must admit that I learned a great deal only after I arrived in Helsinki as a Fulbright student. And most of what I learned was "on the job", through reading for my dissertation. In the beginning, I was not a degree student, just a visiting postgraduate student writing my dissertation. By the time I transferred to become a degree student in folklore studies at the University of Helsinki two years later, I had nearly finished the manuscript which would become my licentiate thesis. Because of this, I took very few actual courses at the Folklore Studies Department, and gained most of my knowledge by reading and asking a lot of questions. I must say that all the professors and researchers I talked to were very patient with me, and I received help from a large number of persons, especially at the university and the Finnish Literature Society.

\section{Could you name some of the theorists who have been influential in your studies?}

My doctoral dissertation work was influenced mostly by anthropological theorists such as Mary Douglas, and anthropological gender theorists such as Michelle Rosaldo, Jane Collier, and Marilyn Strathern. Naturally, the groundwork of my dissertation research had already been laid by numerous Finnish folklorists, ethnologists, and historians. My more recent work has been influenced more by sociologists such as Anthony Giddens and Pierre Bourdieu as well as ethnologist Michel De Certeau, and by social psychologists such as Rom Harré, Kenneth Gergen, and John Shotter. I feel I am always trying to find new ways in which folklore source materials can speak to broader issues about the relation between individual and society, historical changes in concepts of self and person, and early modern experiences and mentalities.

\section{ACADEMiC CAREER In FinLAND}

\section{Describe your academic career, its course and turning points.}

I've been very lucky to have received a lot of support from colleagues and foundations here in Finland. An important mentor has been Professor Satu Apo at the Univeristy of Helsinki. I was very fortunate that we share similar interests, and she has always been a source of help. As a post-doctoral researcher, I was extremely fortunate to be a participant in two groups which have strongly influenced how I think about research: the Academy-funded project Modernization and Popular 


\section{Laura Aro \& MaArit KnUUtTila}

Experience in Finland 1860-1960 (2002-2004), and the Helsinki Collegium for Advanced Studies (2003-2005). The experiences of getting to know fellow researchers in both of these contexts have been very important to me.

In autumn of 2005, I came to the University of Jyväskylä to start work as a Professor of Ethnology at the Department of History and Ethnology. It has been a wonderful experience to be welcomed into an interdisciplinary department with colleagues from so many different intellectual backgrounds, and to be surrounded by students who are so active and enthusiastic. I feel fortunate to be here, and look forward to what the future will bring!

What are the main differences and similarities between Finnish and American scholars in folklore studies?

The first difference which is noticeable is the kind of source materials that American folklorists use most often. They usually have very little archival source materials at their disposal, so they tend to concentrate on fieldwork. Also, American folklorists can often find jobs as 'public folklorists', in which they work for cities and local governments to develop appreciation and understanding of ethnic cultures and differences, and to encourage the celebration of local culture and history. For this reason, many U.S. folklorists work outside of academia.

And what are the main differences between Finnish and American university teaching, especially in the field of folklore? What should, or could be imported from U.S. to Finland and vice versa?

It may be difficult to import American models to Finland or Finnish models to America, because the way in which higher education is organized is entirely different in these countries. The largest difference is money, and where it comes from. In America, nearly every undergraduate student pays enormous fees every year to attend university, and so this means a lot of money coming into the university system. This money pays for teaching salaries and research money for postgraduate students, so that postgraduate students rarely need to apply for money from foundations. For this reason too, research projects with outside funding are less common. Postgraduate students conduct much of the teaching of undergraduates. These postgraduate teachers are known as "teaching assistants", because they are usually assisting a senior professor grading examinations, holding smaller seminars connected to a larger lecture course, etc., and their salaries are relatively high, certainly enough to live on. The drawback of this system is that the undergraduates, by the time they have earned their Bachelor's degrees, often have taken out enormous student loans and so are burdened with heavy debt before they start their working life - I know, because after all these years I'm still paying off my own student debt! 
There are probably many things which could be improved in American universities, but since I've had more time in recent years to observe the Finnish university system, I will mention two things that I think could be stressed more in Finnish universities. First, students would certainly benefit by receiving more feedback from professors and lecturers regarding their performance on examinations and essays. Second, general writing skills should be stressed in lectures and seminars even more than they are now. Greater efforts in these two areas would lay a stronger foundation for a well-rounded education that could best serve Finnish society at large, in my opinion.

What are the strengths of Finnish folklore in international perspective?

Finnish scholars take folklore very seriously and are interested in doing basic research regarding the role of verbal expressiveness in culture, among other important issues. Finnish scholarship is grounded in solid bodies of empirical source materials, and there has always been an interest in developing scientific theory one step further. Finnish folklore studies has a long tradition of adventurous field workers who gather vital data from places where other folklorists do not always go, and this tradition continues today. In addition, Finnish folklore studies are geographically well situated to carry out important comparative folklore research, both in Western Europe and in the former Soviet Union.

Tell about yourpast and present personal scientific interests. How have they changed, and can you tell why?

Well, the Finnish Literature Society Folklore Archives have always fascinated me. For me they represent an enormous treasure trove, and I feel that there is so much to be learned from all the thoughts, memories, events and stories that have been recorded from hundreds of thousands of Finns who lived in a past world which is now lost to us. Most other European countries do not have folklore archives on this scale, and in this sense Finnish folklorists are extremely lucky. I feel that I'm always trying to find new theoretical perspectives and methodologies with which to approach these diverse materials.

\section{Professor IN FOLKLORE STUdies}

\section{Which areas or ideas are you going to emphasize as a professor in folklore studies?}

I think that in the ideal situation, professors should teach what they themselves know best. I'm interested in a wide range of issues and topics, many of which I've never had the chance to study as fully as I would have liked, but teaching provides a way for me to learn together with my students. I myself am interested in narrativity, 
oral culture, early modern mentalities, folk religion, magic and witchcraft, gender studies, body theory, internet folklore, and Kalevala-meter poetry, especially incantations. I'm also interested in issues of social change, such as modernization and secularization in Finland and the West. I think that folklorists and historians have many areas of interest in common, and can help one another to better understand each other's source materials and research approaches.

In terms of theory, I think it is important to not only ground students in the basic theoretical approaches which have been central to our discipline, but to also introduce folklore students to theories from outside our field. For instance, theories from anthropology, sociology, cultural history, literary history and social psychology, to name a few, can help us to understand our research subjects - whether interview subjects, archival texts, or cultural performances - in new and fruitful ways.

PhD Laura Aro is a Docent of Folkloristics in the Department of History and Ethnology, University of Jyväskylä.

MA Maarit Knuuttila is a researcher of Ethnology in the Department of History and Ethnology, University of Jyväskylä. 